\title{
Impact of oxidative metabolism on the production of ATP
}

\author{
Pedro Octavio Barbanera ${ }^{1,2}$ \\ ${ }^{1}$ Department of Chemistry and Biochemistry, University of State of São Paulo, Brazil \\ ${ }^{2}$ Anhanguera Educational- Santa Barbara D'Oeste, Brazil
}

Submission: May 30, 2018; Published: June 21, 2018

*Corresponding author: Pedro Octavio Barbanera, Department of Chemistry and Biochemistry, University of State of São Paulo - São Paulo/Brazil, Email: pedro.barbanera@gmail.com

\section{Abstract}

Antoine Lavoisier (1743-1794) announced the modern concepts of metabolism including thermodynamic distinctions were refined recognizing the type of fuel oxidation and passing through almost 150 years before the creation of metabolic biochemistry.

The cells in the body require an energy system in order to remain alive and reproduce themselves. The body needs substrates as carbohydrates and fats from the food. These energy substrates are oxidized by the cell, producing energy. Both respiration as combustion, the difference between the energy loss of glucose and fat oxidation is often refers to combustion efficiency. In addition, there are discussed situations that differentiate the use of glucose and lipids to produce ATP.

Keywords: Oxidative metabolism; Fuel oxidation; Metabolic biochemistry; Cell; Producing energy; Glucose; Fat oxidation

\section{Introduction}

Antoine Lavoisier (1743-1794) announced the modern concepts of metabolism, nutrition and physiology of the exercise. His discoveries in the process of chemistry respiration were elementary. Lavoisier paved the way for studies of energy balance in recognizing, by the first time, that the elements as carbon, hydrogen and oxygen does not appear subtly and disappeared mysteriously. His achievements provided basic truths: only oxygen participate in the breathing animal, and "caloric" released during respiration and is itself the source of combustion [1]. Right before thermodynamic distinctions were refined recognizing the type of fuel oxidation and passing through almost 150 years before the creation of metabolic biochemistry: with the oxidation of glucose, 1 liter of $\mathrm{O}_{2}$ uptake $\approx 21.1 \mathrm{~kJ}$; with the oxidation of fat, 1 liter of $\mathrm{O}_{2}$ uptake $\approx 19.6$ $\mathrm{kJ}$. According to the description, the difference between $1.5 \mathrm{~kJ}$ substrates seems to influence the $\mathrm{O}_{2}$ consumption based on the energy demand cell [2]. However, in some cases, the distinction substrate ceases to be considered, because the measurement of $\mathrm{O}_{2}$ uptake in and of itself has been used to "measure" energy costs.

The cells in the body require an energy system in order to remain alive and reproduce themselves. The body needs substrates, namely carbohydrates and fats from the food. These energy substrates are oxidized by the cell, producing energy [3]. Subsequently, it was discovered that the amount of consumed oxygen and carbon dioxide eliminated varying with the ingested food. Later the relationship $\mathrm{CO}_{2} / \mathrm{O}_{2}$ was identified as respiratory quotient [3].

\section{Combustion of glucose and fat oxidation: the presence of oxygen for atp production}

Both respiration as combustion, the difference between the energy loss of glucose and fat oxidation is often refers to combustion efficiency. However, the addition of anaerobic metabolism with resynthesis of ATP to complete glucose oxidation respiratory further contributes to the loss of energy in the form of entropy changes; combustion and oxidation of fats/lactate oxidation lack. Indeed, the presence or absence of an anaerobic energy expenditure component should be applied for the estimation of energy costs with respect to glucose, lactate, and oxidation of the fuel, especially when the measurement of oxygen consumption can only set incorrectly energy expenses $[1,4]$.

The fact is that fuel efficiency can vary between oxidized substrates. Heat loss variance is indicative of the size of molecules undergoing combustion, i.e., larger molecules tend to have more connection types connected, smaller molecules less, so that greater variability in the heat (energy) loss is evident when molecules smaller as glucose is burned and compared with the larger, as the fat [4]. This also occurs for respiratory oxidation. However, over a series of biochemical reactions, compared with the oxidation combustion [5]. 
The bomb calorimeter provides consistent evidences of energetic differences between the substrates. Both respiration oxidative and combustion, $1.5 \mathrm{~kJ}$ per liter of $\mathrm{O}_{2}$ difference between glucose and fat is often used to efficiency of the fuel. Rather, the law of William Thornton, presents a quite remarkable similarity in heat loss between the various gases undergoing combustion. With the loss of heat by $\mathrm{O}_{2}$ (electrons) equivalent more like one constant in accordance with the energy equivalent of fat not glucose oxidation.

\section{Conclusion}

A warning from any biochemistry text offers a very succinct explanation of the difference in respiratory glucose oxidation and energy loss that would be different from fat. Energy expenditure powered by fat oxidation is completely represented as mitochondrial uptake of $\mathrm{O}_{2}$. But before the aerobic oxidation of glucose derived within the mitochondria and energy exchange called glycolysis and occurs that yields
ATP does not consume oxygen. And finally, is our attempt to estimate ATP turnover that is our need to quantify energy exchange. It seems, then, that in addition to the internal power of the molecule metabolic processes the respiratory how complete glucose oxidation occurs also require deliberation.

\section{References}

1. Mcardle WD, Katch FI, Katch VL (2011) Fisiologia do Exercício.7ạed. Rio de Janeiro: Guanabara Koogan.

2. Molé PA, Hoffmann JJ (1999) $\mathrm{VO}_{2}$ kinetics of mild exercise are altered by RER. J App Phy 87(6): 2097-2106.

3. Burton B (1979) Metabolismo energético. In: Nutrição humana.Editora McGraw-Hill do Brasil, Sáo Paulo, p. 23-33.

4. Scott CB, Djurisic Z (2008) The metabolic oxidation of glucose: thermodynamic considerations for anaerobic and aerobic energy expenditure. J Ex Phy 11(4): 34-43.

5. Thorton RM (1917) The relation of oxygen to the heat of combustion of organic compounds. Phil Mag 33: 196-203.

\section{Your next submission with Juniper Publishers will reach you the below assets}

- Quality Editorial service

- Swift Peer Review

- Reprints availability

- E-prints Service

- Manuscript Podcast for convenient understanding

- Global attainment for your research

- Manuscript accessibility in different formats

( Pdf, E-pub, Full Text, Audio)

- Unceasing customer service

Track the below URL for one-step submission https://juniperpublishers.com/online-submission.php 